University of Nebraska - Lincoln

DigitalCommons@University of Nebraska - Lincoln

1997

\title{
Herbicides and Their Metabolites in Rainfall: Origin, Transport, and Deposition Patterns across the Midwestern and Northeastern United States, 1990-1991
}

\author{
Donald Goolsby \\ U.S. Geological Survey \\ E. Michael Thurman \\ U.S. Geological Survey \\ Michael Pomes \\ U.S. Geological Survey \\ Michael Meyer \\ U.S. Geological Survey, mmeyer@usgs.gov \\ William Battaglin \\ U.S. Geological Survey
}

Follow this and additional works at: https://digitalcommons.unl.edu/usgsstaffpub

Part of the Earth Sciences Commons

Goolsby, Donald; Thurman, E. Michael; Pomes, Michael; Meyer, Michael; and Battaglin, William, "Herbicides and Their Metabolites in Rainfall: Origin, Transport, and Deposition Patterns across the Midwestern and Northeastern United States, 1990-1991" (1997). USGS Staff -- Published Research. 79.

https://digitalcommons.unl.edu/usgsstaffpub/79

This Article is brought to you for free and open access by the US Geological Survey at DigitalCommons@University of Nebraska - Lincoln. It has been accepted for inclusion in USGS Staff -- Published Research by an authorized administrator of DigitalCommons@University of Nebraska - Lincoln. 


\section{Herbicides and Their Metabolites in Rainfall: Origin, Transport, and Deposition Patterns across the Midwestern and Northeastern United States, $1990-1991$}

\author{
DONALD A. GOOLSBY,*,† \\ E. MICHAEL THURMAN, \\ MICHAEL L. POMES, \\ MICHAEL T. MEYER, § AND \\ WILLIAM A. BATTAGLIN'
}

U.S. Geological Survey, Box 25046, MS 406, DFC, Denver, Colorado 80225, U.S. Geological Survey, 4821 Quail Crest Place, Lawrence, Kansas 66049, and U.S. Geological Survey, 3916 Sunset Ridge Road, Raleigh, North Carolina 27607

Herbicides were detected in rainfall throughout the midwestern and northeastern United States during late spring and summer of 1990 and 1991. Herbicide concentrations exhibited distinct geographic and seasonal patterns. The highest concentrations occurred in midwestern cornbelt states following herbicide application to cropland. Volumeweighted concentrations of $0.2-0.4 \mu \mathrm{g} / \mathrm{L}$ for atrazine and alachlor were typical in this area during mid-April through mid-J uly, and weighted concentrations as large as 0.6$0.9 \mu \mathrm{g} / \mathrm{L}$ occurred at several sites. Concentrations of $1-3$ $\mu \mathrm{g} / \mathrm{L}$ were measured in a few individual samples. Atrazine was detected most often followed by alachlor, deethylatrazine, metolachlor, cyanazine, and deisopropylatrazine. The high ratio $(\sim 0.5)$ of deethylatrazine to atrazine in rainfall suggests atmospheric degradation of atrazine. Mass deposition of herbicides was greatest in areas where herbic ide use was high and decreased w ith distance from the cornbelt. Estimated deposition rates for both atrazine and alachlor ranged from more than $240 \mu \mathrm{g} \mathrm{m}^{-2}$ $\mathrm{yr}^{-1}$ for some areas in the midwestern states to less than $10 \mu \mathrm{g} \mathrm{m}^{-2} \mathrm{yr}^{-1}$ for the New England states. The estimated annual deposition of atrazine on the Great Lakes ranged from about 12 to $63 \mu \mathrm{g} \mathrm{m}^{-2} \mathrm{yr}^{-1}$. The total a mounts of atrazine and alachlor deposited annually in rainfall in the study area represent about $0.6 \%$ of the atrazine and $0.4 \%$ of the alachlor applied annually to crops in the study area.

\section{Introduction}

Current agricultural practices in the United States require extensive use of herbicides for economical production of corn, soybeans, sorghum, and other row crops. Data compiled in 1991 (1) show that about two-thirds of the estimated 218 million $\mathrm{kg}$ of herbicides used annually for agriculture in the United States (2) are applied to cropland in the Midwest, principally in the Mississippi River drainage basin. This

\footnotetext{
*Corresponding author telephone: 303-235-5950; fax: 303-2365919; e-mail: dgoolsby@usgs.gov.

+ U.S. Geological Survey, Denver, CO.

₹ U.S. Geological Survey, Lawrence, KS.

$\S$ U.S. Gelogical Survey, Raleigh, NC.
}

region, referred to as the cornbelt, extends from central Nebraska eastward across I owa, southern Minnesota, Illinois, Indiana, and Ohio. As a consequence of the high use of herbicides, this region is a major source area for transport of herbicides into streams, groundwater, and the atmosphere. Most herbicides are relatively soluble in water, and a small percentage of the amounts applied annually is transported into streams during storm runoff ( $3-7)$ and to groundwater (8-10). Herbicides and other organic compounds also can be transported into the atmosphere by various processes. Once in the atmosphere, these compounds can be dispersed by air currents and re-deposited on water and land surfaces, often at considerabledistances from their origin. For example, thetransport of chlorinated insecticides and polychlorinated biphenyls (PCBs) into the Great Lakes is largely from atmospheric sources (11). Morethan two dozen agricultural pesticides have been reported in fog and rainfall in theUnited States (12-20), Canada (21), and Europe $(22,23)$. Examples of these pesticides include carbamate insecticides (carbaryl and carbofuran), organochlorine insecticides (chlordane, DDT, lindane, mirex, and toxaphene), and organophosphorus insecticides (chloropyrifos, diazinon, fonofos, malathion, methidathion, and parathion). However, triazine and acetanilide herbicides such as atrazine, alachlor, and metolachlor are the most frequently reported pesticides in rainfall and occur in the highest concentrations. This is especially true in the midwestern United States where herbicide concentrations as high as $40 \mu \mathrm{g} / \mathrm{L}$ have been reported in bulk rainfall (14). In spite of these studies, relatively little is known on a regional or multistate scale about the occurrence and deposition patterns of herbicides in rainfall over large geographic areas or how the amounts of herbicides deposited annually in rainfall compare to annual quantities applied to cropland or to annual losses in surface runoff.

To learn more about herbicides in rainfall on a regional scale, the U.S. Geological Survey conducted a study during 1990 and 1991 to investigate the occurrence and deposition of selected herbicides in rainfall (rain and snow) for a large part of the United States. The study area (Figure 1) covered about a quarter of the conterminous U nited States and much of the Mississippi River basin where herbicide use is most intense. The purposes of the study wereto (1) determine the occurrence and temporal distribution of major cornbelt triazine and acetanilide herbicides in rainfall over a large part of the United States; (2) estimate the annual mass deposition in rainfall for atrazine and alachlor, the two most heavily used herbicides in 1990 and 1991; and (3) relate the annual deposition of atrazine and alachlor in rainfall to the amounts applied annually to crops. Results from the 19month study are presented in this paper.

\section{Experimental Section}

Study Area and Sampling Protocol. The study area for this investigation encompassed 26 states (Figure 1). It included states in the upper Midwest that contain the majority of the harvested cropland in the United States and where the use of atrazineand alachlor ismost intense (Figure 2A,B). Rainfall samples were obtained through the cooperation and assistance of the National Atmospheric Deposition Program/ National Trends Network (NADP/NTN), Fort Collins, CO, and the Illinois State Water Survey, Champaign, IL. The NADP/ NTN operates a network of about 200 sites nationwide to monitor thestatusand trendsin acid deposition (24). Weekly accumulations of rainfall (rain and snow) were obtained at 81 NADP/ NTN sampling sites located in 23 states within the 26-state study area (Figure 1 ). In addition, four NADP/ NTN sites in high-elevation areas along the Rocky Mountains 


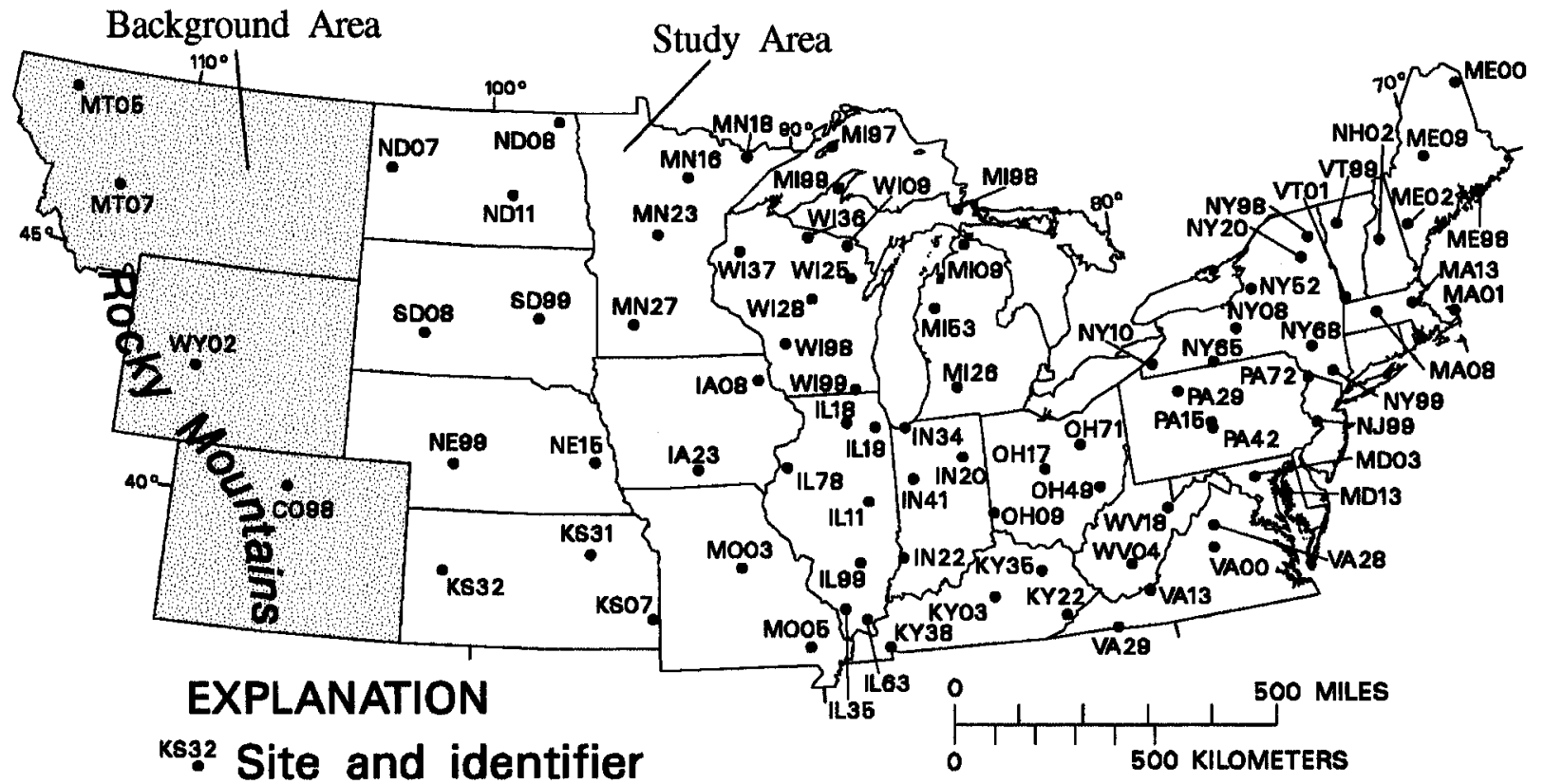

FIGURE 1. Location of study area, background area, and National Atmospheric Deposition Program/National Trends Netw ork sampling sites. (Alaska site AK03 not shown.)

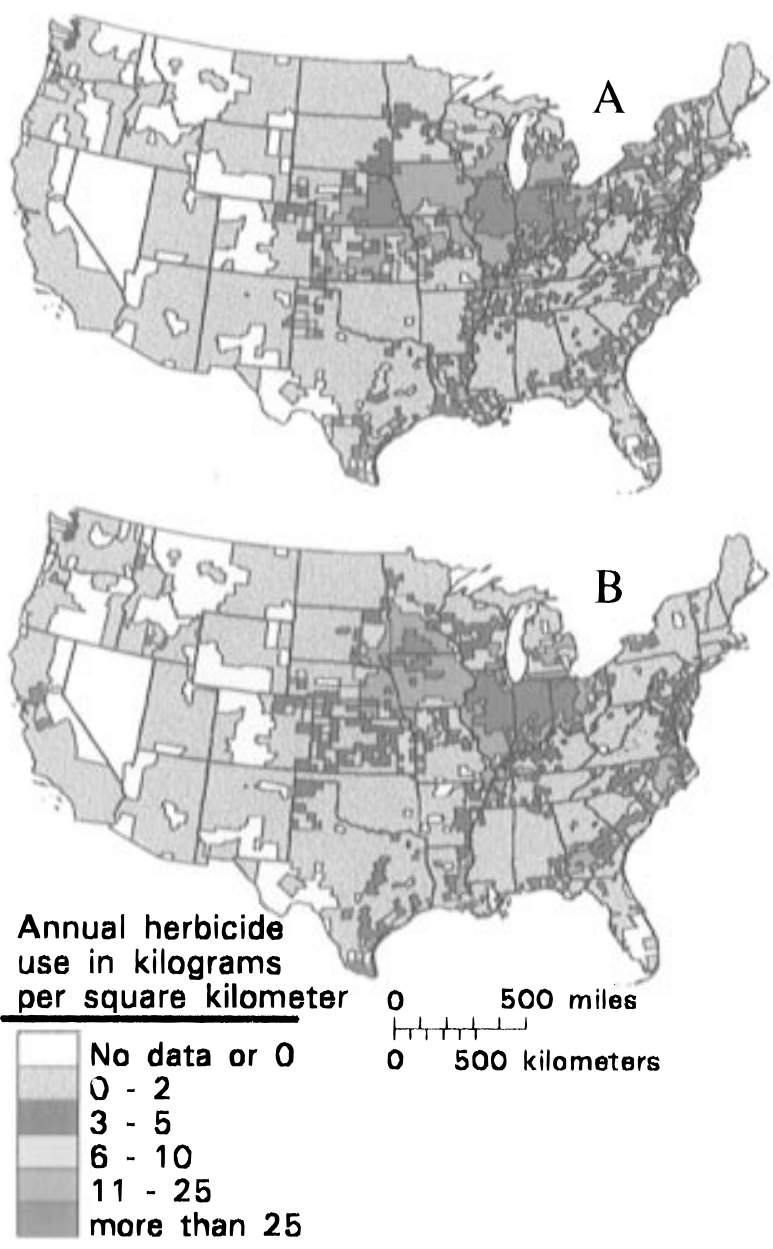

FIGURE 2. Estimated annual use of (A) atrazine and (B) alachlor, by county, in the United States.

(Figure 1) and one site in Alaska (AK03) were sampled to provide background data on herbicides in rainfall at sites far from the study area.

Each NADP/NTN monitoring site was equipped with an Aerochem Metrics wet/ dry sampler equipped with two 13-L polyethylene buckets that alternately collected wet or dry deposition (24). Rainfall was accumulated for a period of 1 week, and each Tuesday, regardless of whether rainfall occurred the previous week, a site operator removed the "wet side" bucket, sealed it with a polyethylene lid, and sent it to the Central Analytical Laboratories (CAL) of the IIlinois State Water Survey in Champaign, IL for analysis. For the 86 NADP/ NTN sites used in this study, a subsample consisting of 10$125 \mathrm{~mL}$ depending on the amount of rainfall collected was transferred to a $125-\mathrm{mL}$ amber heat-cleaned glass bottle, chilled, and sent to the U.S. Geological Survey's laboratory in Lawrence, KS, for herbicide analysis. Buckets from sites where no rainfall occurred the previous week were used as system bucket blanks. No samples of dry deposition were analyzed in this study.

All samples were analyzed by enzyme-linked immunosorbent assay (ELISA) for both alachlor and atrazine. Samples in which herbicides were detected by ELISA and that had a sample volume of at least $60 \mathrm{~mL}$ were analyzed by gas chromatography/mass spectrometry (GC/MS) to determine the concentrations of selected herbicides. Samples with volumes less than $60 \mathrm{~mL}$ werenot analyzed by GC/MS. About $10 \%$ of all negative ELISA samples also were analyzed by GC/ MS. These samples were chosen randomly from all negative samples.

ELISA Analysis. Resi-Quant immunoassay kits (Immunosystems, Scarborough, ME) were used for the ELISA analyses using procedures described by Thurman and others (4). Standards were analyzed in triplicate or quadruplicate. Samples were analyzed in duplicate and the results averaged. The relativestandard deviation for atrazineranged from $\pm 60 \%$ at $0.1 \mu \mathrm{g} / \mathrm{L}$ to $\pm 15 \%$ at $1.0 \mu \mathrm{g} / \mathrm{L}$, based on analysis of duplicates (25). For alachlor, the relativestandard deviation ranged from $\pm 73 \%$ at $0.15 \mu \mathrm{g} / \mathrm{L}$ to $\pm 22 \%$ at $1.0 \mu \mathrm{g} / \mathrm{L}$. Reporting limits were $0.1 \mu \mathrm{g} / \mathrm{L}$ for atrazineand $0.15 \mu \mathrm{g} / \mathrm{L}$ for alachlor. However, because the ELISA methods are not $100 \%$ specific for atrazine and alachlor, the ELISA results from this study are referred to as triazines and acetanilides.

GC/MS Analysis. Samples selected for GC/MS confirmation were isolated on C-18 solid-phase extraction cartridges (26) and analyzed on a Hewlett-Packard Model 5890 GC (Palo Alto, CA) and a 5970A mass selective detector (27). Eleven parent herbicideswere analyzed by GC/MSanalysis: alachlor, ametryn, atrazine, cyanazine, metolachlor, metribuzin, prome- 
TABLE 1. Summary of Herbicide Concentrations Measured in Rainfall Samples from 81 National Atmospheric Deposition Program/ National Trends Network Sites during March 1990 -September $1991^{\text {a }}$



ton, prometryn, propazine, simazine, and terbutryn. Two metabolites of atrazine, deethylatrazine and deisopropylatrazine, were also analyzed by GC/MS.

\section{Quality Assurance}

Samples Analyzed. A total of 6230 samples were analyzed by ELISA during this study. These included 5595 samples from the study area and background area (see Figure 1), 309 blanks, and 326 other quality control samples. About $38 \%$ of the samples werealso analyzed by GC/MS. About $11 \%$ of the samples analyzed werefor quality control purposes. Quality assurance included experiments to determine if the NADP polyethylene collection buckets had an effect on the concentration of herbicides analyzed in this study. Both clean bucket blanks and system bucket blanks were analyzed regularly to determine if the sample buckets caused sample contamination.

Collection Container Experiments. Prior to undertaking this study, experiments were conducted to determine if the polyethylene collection buckets caused sorption, leaching, or degradation of theherbicides analyzed. Analytical results from these experiments, described elsewhere (28), showed no significant difference between herbicide concentrations in samplesstored in the polyethylene buckets and those stored in glass containers within analytical error. These results (28) also confirmed that no significant sorption, degradation, or other losses of the major herbicides analyzed occurred in the buckets for periods of 3 weeks.

Blanks. Each week the Illinois State Water Survey Laboratory prepared a clean bucket blank by placing $125 \mathrm{~mL}$ of distilled water in contact with a clean polyethylene bucket for $24 \mathrm{~h}$. Of the 62 clean bucket blanks analyzed during the study, $10 \%$ had triazine concentrations above the ELISA reporting limit of $0.1 \mu \mathrm{g} / \mathrm{L}$, and the maximum concentration detected by ELISA was $0.22 \mu \mathrm{g} / \mathrm{L}$. For acetanilides, $2 \%$ of the samples had concentrations above the ELISA reporting limit of $0.15 \mu \mathrm{g} / \mathrm{L}$, and the maximum concentration measured was $0.32 \mu \mathrm{g} / \mathrm{L}$. No herbicides were detected in 20 clean bucket blanks analyzed by GC/MS. These results indicate that little or no herbicidecontamination was contributed by thesample collection buckets.

System blanks were collection buckets from NADP/NTN sites where no rainfall occurred the previous week. These buckets were leached for $24 \mathrm{~h}$ with $50 \mathrm{~mL}$ of distilled water and used to determine if contamination by herbicides had occurred anywhere during the week-long sampling process. Of the 247 system blanks analyzed during the study, 9\% contained detectable triazines and 3\% contained detectable acetanilides as measured by ELISA. The percentage of system blanks with herbicide detections was essentially not different from the clean bucket blanks.

Correlation between ELISAand GC/MSAnalyses. Linear regression equations, given below, were developed from the 2085 rainfall samples analyzed for atrazine and alachlor by both ELISA and GC/MS methods. The regression equations were then used to estimate the atrazine and alachlor concentration in the 3212 samples analyzed only by ELISA. Because of slight changes in methodology and differing batches of ELISA antibodies, regression results wereimproved slightly by developing separate equations for samples collected in 1990 and 1991.

1990:

atrazine $=-0.01+0.70$ ELISA; $R^{2}=0.94$ standard error of estimate $=0.09 \mu \mathrm{g} / \mathrm{L}$.

1991:

atrazine $=0.00+0.80$ ELISA; $R^{2}=0.78$; standard error of estimate $=0.10 \mu \mathrm{g} / \mathrm{L}$

1990:

$$
\begin{aligned}
\text { alachlor }= & 0.00+0.64 \text { ELISA; } R^{2}=0.76 ; \\
& \text { standard error of estimate }=0.08 \mu \mathrm{g} / \mathrm{L}
\end{aligned}
$$

1991:

alachlor $=0.00+0.84$ ELISA; $R^{2}=0.86$ standard error of estimate $=0.09 \mu \mathrm{g} / \mathrm{L}$ (4)

The slopes of the regression lines varied from 0.64 to 0.84 , indicatingthat somewhat lower concentrations were obtained by GC/MS than by ELISA. This can be attributed, in part, to thecross reactivity of theELISA antibodies with other triazine and acetanilide compounds. However, herbicides having significant reactivity with the ELISA methods other than atrazine and alachlor were rarely detected in this study and should have little effect on theELISA analysis. In the following discussion, reference to atrazine and alachlor pertains to concentrations of these herbicides measured by GC/ MS and concentrations estimated from ELISA results and regression eqs 1-4 for samples not analyzed by GC/MS.

\section{Results and Discussion}

Concentrations of Herbicides in Rainfall. Table 1 contains asummary of the occurrenceand concentrations of herbicides 


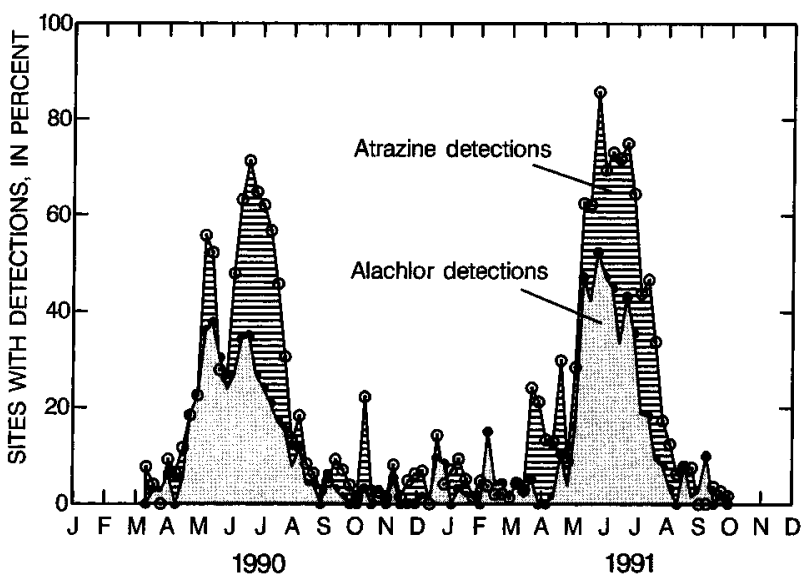

FIGURE 3. Frequency of atrazine and alachlor detections, by w eek, for 81 sites in the study area. (Includes detections by ELISA and GC/MS.)

detected in samples collected during the 19-month study period. Concentration data for the individual sampling sites have been published elsewhere (28). About one-third of the 5297 samples from the study area contained detectable concentrations of triazines and/or acetanilides. Ten of the 13 herbicides and metabolites analyzed were detected. The most frequently detected herbicides were atrazine, and alachlor which were present in $30.2 \%$ and $19.2 \%$ of thesamples analyzed by GC/MS. These two herbicides also occurred in the highest concentrations. Deethylatrazine was the third most frequently detected compound in the GC/MS analyses (17.4\%), followed by metolachlor (13.3\%), and cyanazine (7.2\%). Five other herbicides and metabolites were detected in fewer than $3 \%$ of the samples. Although herbicides were detected in a significant number of samples, concentrations were relatively low. Only about $1 \%$ of the samples had herbicide concentrations exceeding $1 \mu \mathrm{g} / \mathrm{L}$ and only about $10 \%$ of the concentrations exceeded $0.2 \mu \mathrm{g} / \mathrm{L}$. Herbicides were detected most frequently at sites in the midwestern states. However atrazine and/ or alachlor were detected and confirmed by GC/MS in samples from 23 states in the study area. Atrazine was detected in low concentrations at sites remote from cropland, such as Maine and Isle Royale in northern Lake Superior. Atrazine and/or alachlor also were confirmed by GC/MS in about $4 \%$ of the 298 samples from background sites (Figure 1) in the Rocky Mountains and Alaska.

Figure 3shows that the occurrence of atrazineand alachlor in rainfall ishighly seasonal. The detection frequency of these two herbicides at the 81 sampling sites began to increase in mid-April following application of herbicides to cropland and peaked in late May or early June. During this period in both 1990 and 1991 atrazine was detected at about $70-75 \%$ of the sites sampled each week, and alachlor was detected at about $35-45 \%$ of the sites. After early July 1990, the number of sites with herbicide detections began to decrease, and by late August herbicides were detected at less than $10 \%$ of the sites. Detections remained low until the following March (1991) when the pattern was repeated.

Figure 4 shows the temporal distribution of atrazine and alachlor concentrations at four representative sites selected from all parts of the study area. The highest concentrations occurred in Mayand June. Thistemporal pattern in herbicide concentration is similar to that observed in Midwestern streams during this time of the year $(4,5)$. Concentrations were highest at sites in the Midwest cornbelt (Figure 4A,B) whereherbicideuseis most intense. Concentrations as high as $3 \mu \mathrm{g} / \mathrm{L}$ were detected in individual samples at some of these sites during mid-April through June. Maximum concentrations in the Midwest were similar to those reported by
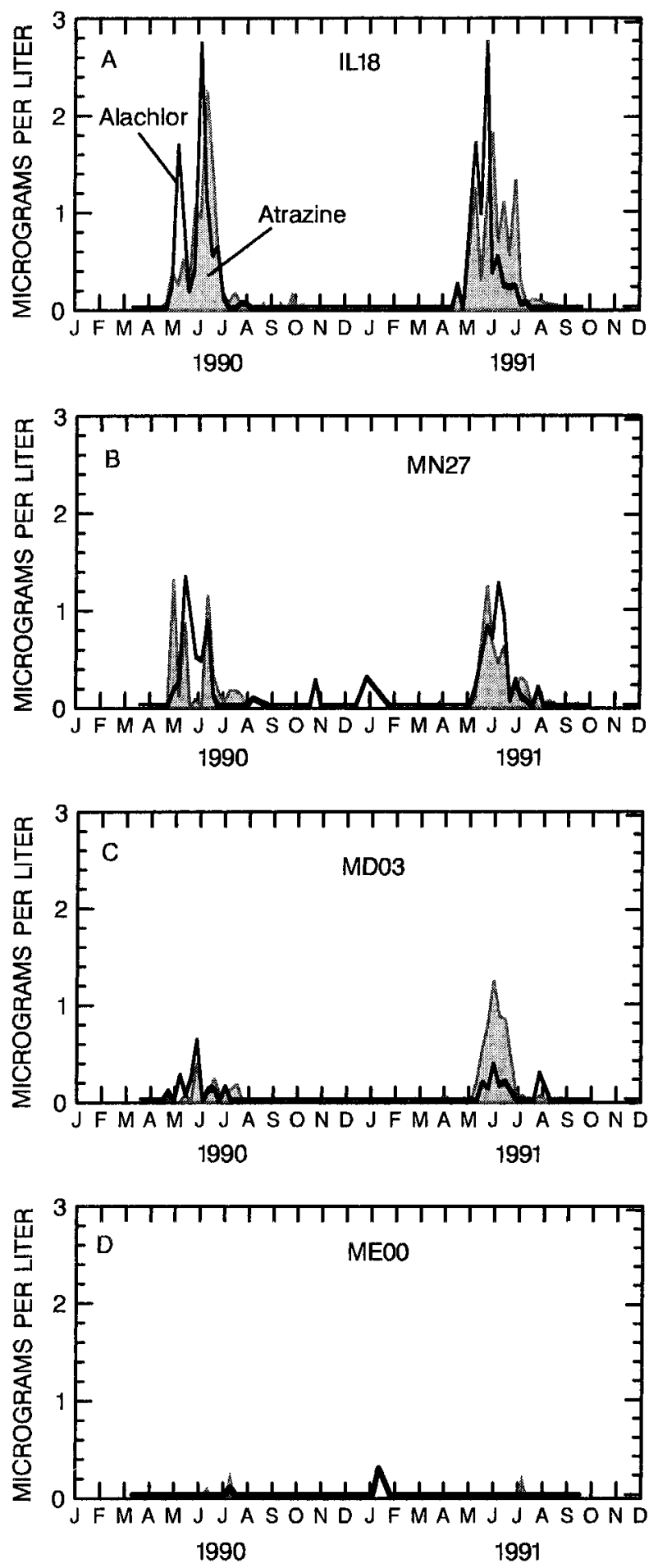

FIGURE 4. Atrazine and alachlor concentrations in precipitation, March 1990-September 1991. Some herbicide concentrations estimated from immunoassay-gas chromatography/mass spectrometry regression equations. Site locations show $n$ in Figure 1.

Richards et al. for sites in Ohio and Indiana (15), but considerably less than maximum concentrations of $40 \mu \mathrm{g} / \mathrm{L}$ reported for bulk precipitation in lowa (14). Elevated herbicide concentrations also occurred in agricultural areas along the East Coast, such as in Maryland (Figure 4C). It should be noted that several of the sampling sites are located at Agricultural Experiment Stations or near cropland. It is not known what effect, if any, the site location may have had on measured concentrations. In areas remote from the Midwest cornbelt, such as Maine (Figure 4D) and parts of Michigan, herbicide concentrations were very low and 
TABLE 2. Some Physicochemical Properties at $25^{\circ} \mathrm{C}$ (Except as Noted) and Soil Half-Lives of Selected Herbicides

\begin{tabular}{|c|c|c|c|c|}
\hline herbicide & solubilitya (mg/L) & vapor pressure $^{a}(\mathrm{mPa})$ & Henry's law a constant $\times 10^{-3}\left(\mathrm{~Pa} \cdot \mathrm{m}^{3} / \mathrm{mol}\right)$ & soil half-life ${ }^{b}$ (days) \\
\hline $\begin{array}{l}\text { alachlor } \\
\text { atrazine }\end{array}$ & $\begin{array}{l}242 \\
33\left(22^{\circ} \mathrm{C}\right)\end{array}$ & $\begin{array}{l}4.13 \\
0.038\end{array}$ & $\begin{array}{l}2.1 \\
0.248\end{array}$ & $\begin{array}{l}15 \\
60\end{array}$ \\
\hline cyanazine & 170 & $0.0002\left(20^{\circ} \mathrm{C}\right)$ & $0.0003\left(23^{\circ} \mathrm{C}\right)$ & 14 \\
\hline metolachlor & $488\left(22^{\circ} \mathrm{C}\right)$ & 4.17 & 2.44 & 20 \\
\hline simazine & $3.5\left(20^{\circ} \mathrm{C}\right)$ & $0.0008\left(20^{\circ} \mathrm{C}\right)$ & 0.098 & 75 \\
\hline
\end{tabular}



FIGURE 5. Scatter plot of atrazine and alachlor concentrations versus amount of precipitation.

detections were infrequent. A few detections of alachlor and atrazine were noted during winter months at sites far from the cornbelt. These detections were at the reporting limit of the ELISA method and may be a result of low precision and sensitivity of this method, as evidenced by several detections of herbicides by ELISA methods in blanks.

In areas where the amounts of atrazine and alachlor used were similar, such as in Iowa, Illinois, and Indiana, peak concentrations of atrazine generally were lower than those of alachlor, but atrazine was usually detected for a longer period of time than alachlor. These differences in temporal patterns can, in part, be attributed to differences in the physiochemical properties and soil half-lives of these two herbicides. The vapor pressure of atrazine is about 100 times less than that of alachlor (Table 2), and the Henry's law constant, which describes thepartitioning between the vapor and water phases, for atrazine is about 10 times less than for alachlor. Consequently, atrazine should volatilize from the soil into the atmosphere more slowly than alachlor. Studies by Glotfelty et al. (29) showed that the daily volatilization loss of atrazine to the atmosphere was about one-tenth that of alachlor. The slower volatilization rate of atrazine into the atmosphere should result in lower peak concentrations of atrazinein rainfall than for alachlor given similar application rates. Conversely, atrazine has a much longer soil half-life (about 60 days) than alachlor (about 15 days). As a result, atrazine should be available on the soil surface for volatilization into the atmosphere for a considerably longer period of time than alachlor. The combined effect of these two processes should be lower peak concentrations of atrazine than alachlor in rainfall near the source of application, but atrazine should be detectable in rainfall for a longer time because of its longer soil half-life. It is well-documented that atrazine is present in surface runoff to midwestern streams for a much longer time than alachlor (4-6). Other factors, such as application technique, also affect the volatilization of herbicides into the atmosphere.

Herbicideconcentrations werehighest during small rainfall events. As shown in Figure 5, the highest concentrations of atrazine and alachlor occurred in samples representing less than about $20 \mathrm{~mm}$ of precipitation, and nearly all concentrations exceeding $1 \mu \mathrm{g} / \mathrm{L}$ occurred in samples representing less than $50 \mathrm{~mm}$ of precipitation. This pattern, which has also been reported by others (13), occurs because the first part of a precipitation event tends to scavengemost of the herbicides from the atmosphere, especially those herbicides associated with particulatematerial. Rainfall occurring later in the event dilutes the concentration of herbicides that were deposited during the early part of the rainfall event and contributes little to the mass of herbicides deposited.

Because of the large temporal and spatial variation in the amount of rainfall, it is difficult to make meaningful comparisons of herbicide concentrations amongsites or over time on the basis of individual weekly samples. Comparisons can best be made with rainfall-weighted concentrations. Figure 6 shows the spatial distribution of rainfall-weighted concentrations of atrazine and alachlor calculated for 13-week periods from mid-April through mid-July of 1990 and 1991 when concentrations in rainfall were highest. Rainfallweighted concentrations of $0.2-0.4 \mu \mathrm{g} / \mathrm{L}$ for both atrazine and alachlor were typical throughout the Midwest for this 13-week period, and weighted concentrations of $0.4-0.9 \mu \mathrm{g} / \mathrm{L}$ were recorded at sites in lowa, Illinois, and Indiana. Overall, the spatial patterns of the weighted atrazine concentrations in 1990 and 1991 were similar and generally reflect the intensity of use of these herbicides (Figure 2). The same is true for alachlor. However, when the spatial pattern of weighted concentrations of atrazineare compared with those of alachlor, differences areobserved (Figure6). Atrazinewas detected over a larger area and at greater distances from the Midwest cornbelt than alachlor. The higher atrazine concentration in the western part of the study area is probably the result of greater use of atrazine than alachlor in this area (see Figure 2). However, the higher atrazine concentrations north and east of the cornbelt cannot be explained by differences in herbicide use. Further, sincethevolatilization rate of alachlor is much greater than atrazine (29), one might expectalachlor concentrations in rain to besimilar to or larger than atrazine in this area. The higher atrazine concentrations in rain suggest that atrazine is being transported over greater distances through the atmosphere than alachlor or that alachlor is less stable in the atmosphere than atrazine, or both. This is in agreement with results reported by Glotfelty et al. (18), who concluded that alachlor was far less stable than atrazine in the atmosphere in eastern Maryland.

Regional Deposition Patterns. Figure 7 shows the regional patterns of atrazineand alachlor deposited in rainfall during March through December 1990 and January through September 1991. Nearly all of the deposition of atrazine and alachlor occurred during April through July when concentrations were highest. Consequently, results shown in Figure 7 should closely represent the total annual wet deposition of atrazine and alachlor during the 2 years. As would be expected, the deposition patterns mirror the concentration patterns shown in Figure 6. Deposition rates ranged from more than $100 \mu \mathrm{g} \mathrm{m}^{-2} \mathrm{yr}^{-1}$ for both atrazine and alachlor at a numerous sampling sites in the midwestern states to less than $10 \mu \mathrm{g} \mathrm{m}^{-2} \mathrm{yr}^{-1}$ in the northeastern states. Deposition rates throughout most of the cornbelt ranged from 50 to more than $100 \mu \mathrm{g} \mathrm{m}^{-2} \mathrm{yr}^{-1}$ for both herbicides. The maximum 


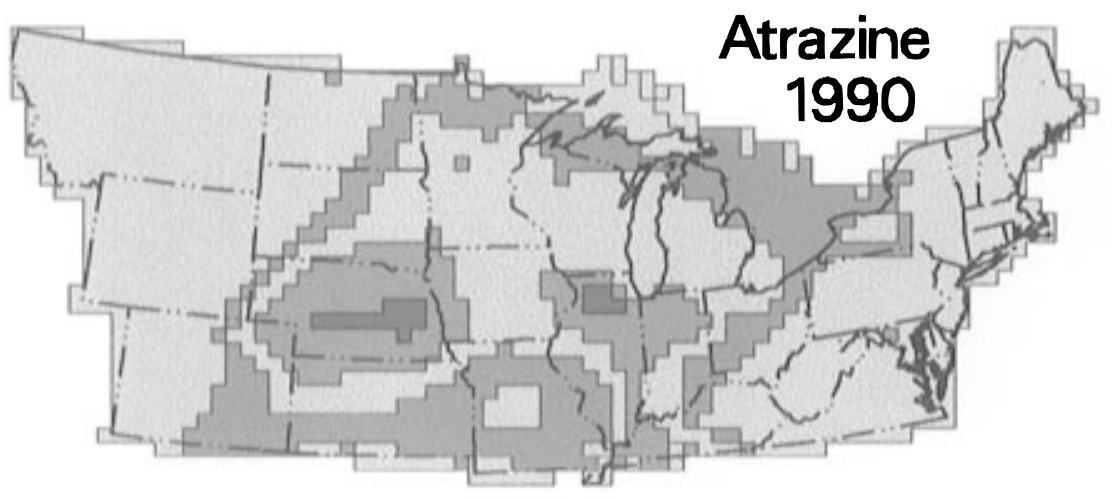

\section{EXPLANATION}



\section{Precipitation-weighted herbicide concentration in micrograms per liter}
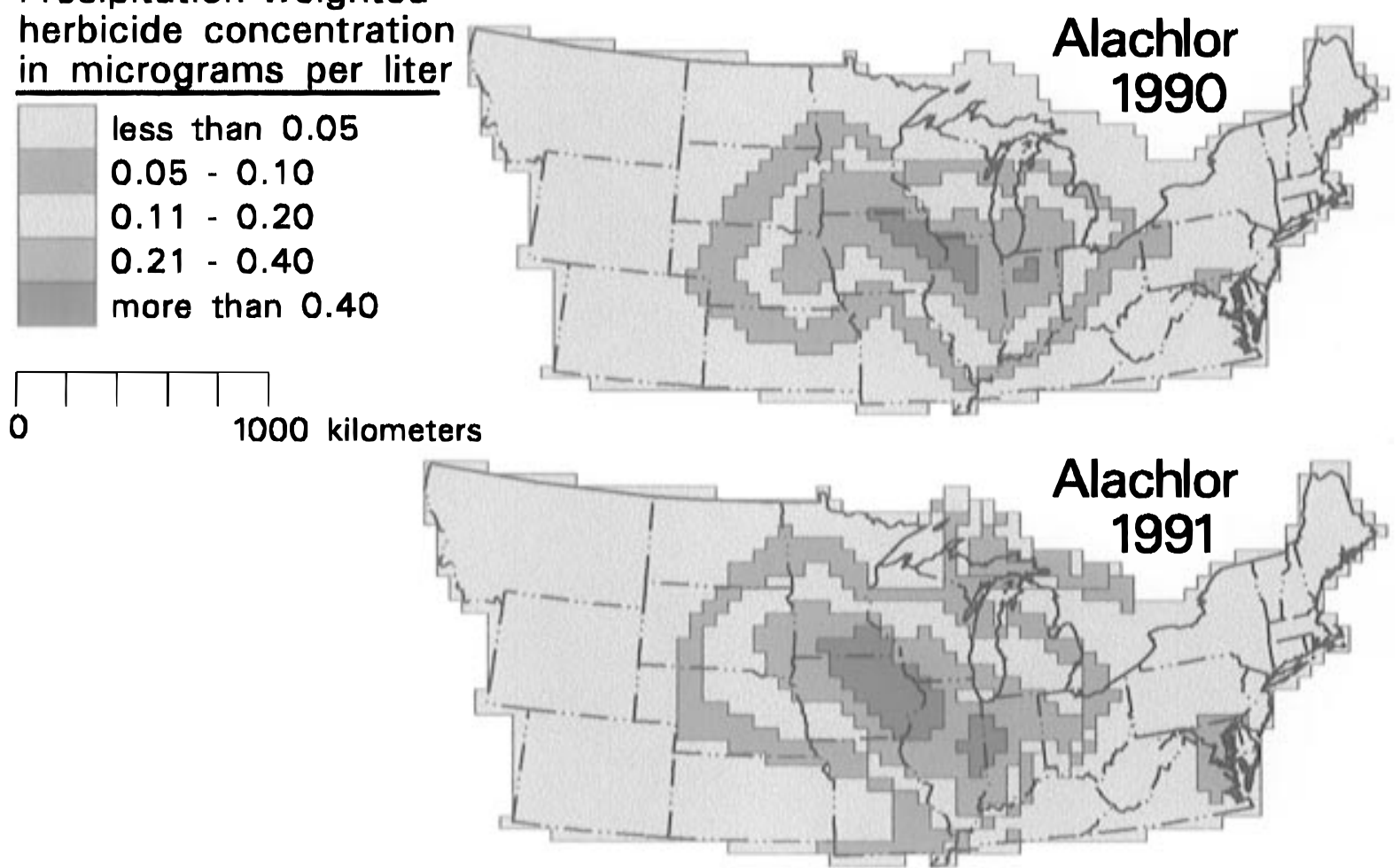

FIGURE 6. Precipitation-weighted concentrations of atrazine and alachlor during mid-April through mid-J uly 1990 and 1991.

deposition rates of morethan $240 \mu \mathrm{g} \mathrm{m}^{-2} \mathrm{yr}^{-1}$ for both atrazine and alachlor occurred at site IL18 located at the Northern Illinois Agricultural Research Center near Shabbona, IL (see Figure 1). Atrazine deposition rates of 11 to more than $60 \mu \mathrm{g}$ $\mathrm{m}^{-2} \mathrm{yr}^{-1}$ were measured in the northeastern United States and in the Great Lakes region. Verylittledeposition of alachlor was measured in these areas.

The total mass of herbicides deposited in rainfall over the entirestudy area during 1991 is estimated to beabout 140000 $\mathrm{kg}$ for atrazine and about $82000 \mathrm{~kg}$ for alachlor (Table 3). These amounts represent about $0.6 \%$ and $0.4 \%$, respectively, of the annual amounts of atrazine and alachlor applied to cropland in the study area and are much smaller than volatilization losses reported in the literature. For example, Glotfelty et al. (29) reported volatilization losses from soil of $2.4 \%$ for atrazine and $26 \%$ for alachlor over a period of 24 days. A comparison of our results with the reported volatilization indicates that only part of the atrazine and alachlor that volatilizes into the atmosphere is actually redeposited in rainfall.

About $40 \%$ more atrazine than alachlor was measured in wet deposition even though the use of the two herbicides in 


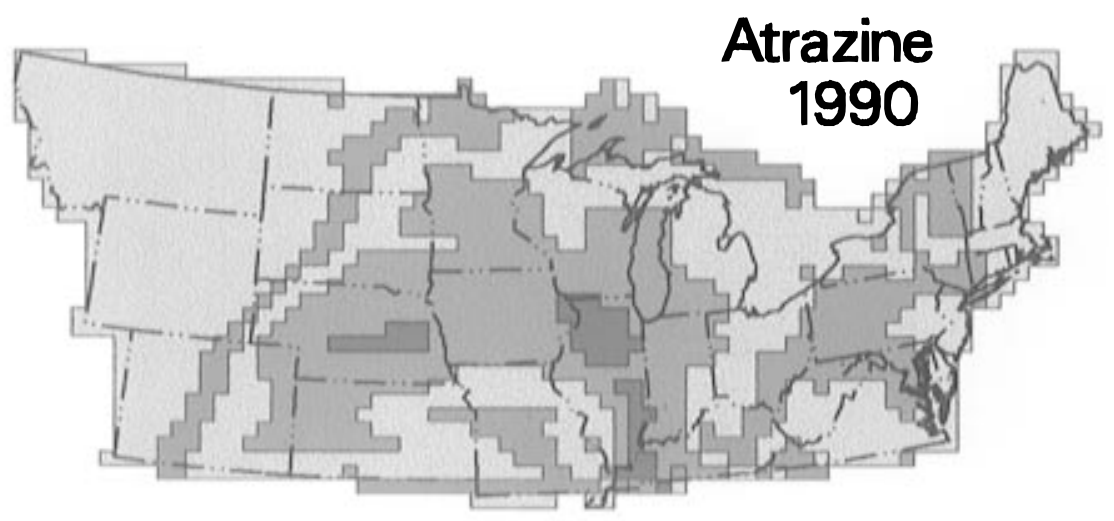

EXPLANATION
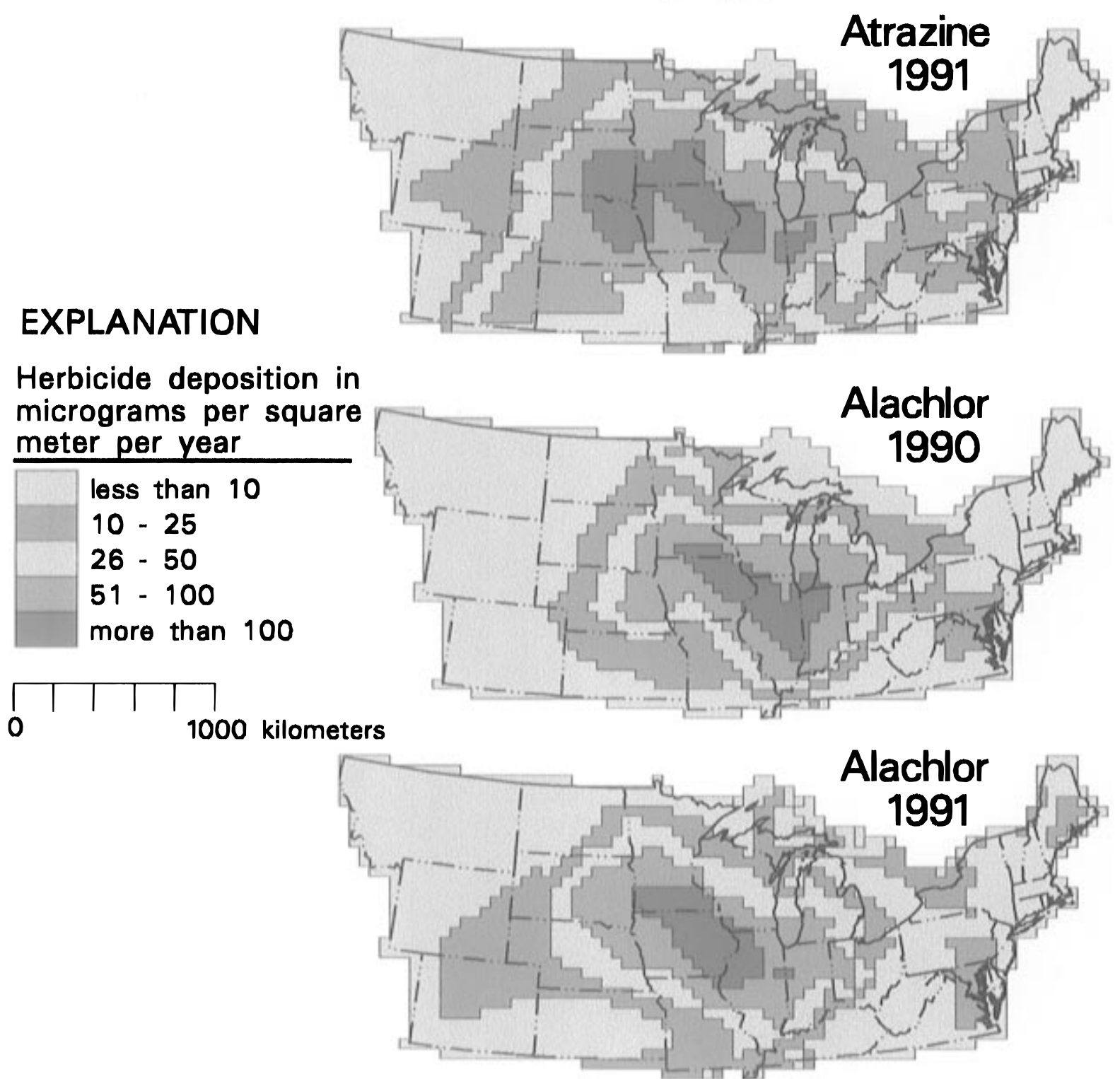

FIGURE 7. Estimated deposition of atrazine and alachlor in precipitation during March through December 1990 and J anuary through September 1991.

the study area was similar. We hypothesize that the large difference in deposition mass measured in rainfall for these two herbicides is, in part, attributable to transport processes. Because of the differences in vapor pressure, more atrazine than alachlor would betransported on particlesthat are more efficiently scavenged by rainfall than are gases. Even $1 \mathrm{~mm}$ of rainfall can effectively cleanse the atmosphere of most particles (20). Conversely, morealachlor than atrazine would betransported in the gas phase. Thesmaller deposition mass of alachlor in rainfall is also consistent with the hypothesis that alachlor is less stable in the atmosphere than atrazine. The processes for atmospheric degradation of alachlor are largely unknown. Experiments conducted by Foreman et al. (32) would seem to rule out direct photolysis. However, reaction with photochemically generated oxidants such as ozone, and hydroxyl, nitrate, or hydroperoxy radicals is plausible.

The study area (see Figure 1) included most of the Mississippi River basin above its confluence with the Ohio River and most of the Ohio River basin. The masses of atrazine 
TABLE 3. Comparison of Atrazine and Alachlor Deposition in Rainfall during 1991 with Annual Usage and Annual Transport from the Upper Mississippi and Ohio River Basins in Streamflow

\begin{tabular}{|c|c|c|c|c|c|}
\hline herbicide & annual use $(\mathrm{kg})$ & w et deposition (kg) & wet deposition as $\%$ of use & transport in streamflow $(\mathrm{kg})$ & transport as $\%$ of use \\
\hline $\begin{array}{l}\text { atrazine } \\
\text { alachlor }\end{array}$ & $\begin{array}{l}23970000 \\
20317000\end{array}$ & $\begin{array}{r}140700 \\
82400\end{array}$ & $\begin{array}{c}\text {-State Study Area (2970 } 000 \mathrm{k} \\
0.59 \\
0.41\end{array}$ & & \\
\hline \multicolumn{6}{|c|}{ Upper Mississippi and Ohio River Basins (2 $400000 \mathrm{~km}^{2}$ ) } \\
\hline $\begin{array}{l}\text { atrazine } \\
\text { alachlor }\end{array}$ & $\begin{array}{l}18460000 \\
17100000\end{array}$ & $\begin{array}{r}112000 \\
69000\end{array}$ & $\begin{array}{l}0.61 \\
0.40\end{array}$ & $\begin{array}{r}246000 \\
47900\end{array}$ & $\begin{array}{l}1.3 \\
0.3\end{array}$ \\
\hline
\end{tabular}

TABLE 4. Estimated Deposition of Atrazine and Alachlor on the Great Lakes Region from Rainfall in 1990 and 1991

\begin{tabular}{|c|c|c|c|c|c|c|c|c|c|c|}
\hline \multirow[b]{3}{*}{ lake } & \multirow[b]{3}{*}{$\operatorname{vol}^{a}\left(\mathrm{~km}^{3}\right)$} & \multirow[b]{3}{*}{ residence time ${ }^{a}$ (years) } & \multicolumn{4}{|c|}{ atrazine deposition } & \multicolumn{4}{|c|}{ alachlor deposition } \\
\hline & & & \multicolumn{2}{|r|}{1990} & \multicolumn{2}{|r|}{1991} & \multicolumn{2}{|r|}{1990} & \multicolumn{2}{|r|}{1991} \\
\hline & & & $\mathrm{kg}$ & $\mu \mathrm{g} \mathrm{m}^{-2} \mathrm{yr}^{-1}$ & kg & $\mu \mathrm{g} \mathrm{m}^{-2} \mathrm{yr}^{-1}$ & kg & $\mu \mathrm{g} \mathrm{m}^{-2} \mathrm{yr}^{-1}$ & kg & $\mu \mathrm{g} \mathrm{m}^{-2} \mathrm{yr}^{-1}$ \\
\hline Lake Michigan & 4920 & 100 & 3640 & 63 & 2380 & 41 & 3060 & 53 & 1420 & 25 \\
\hline Lake Superior & 12230 & 172 & 2140 & 26 & 980 & 12 & 560 & 7 & 160 & 2 \\
\hline Lake Huron & 3537 & 20 & 1930 & 32 & 1190 & 20 & 800 & 13 & 230 & 4 \\
\hline Lake Erie & 483 & 2.3 & 990 & 39 & 920 & 36 & 1030 & 40 & 460 & 18 \\
\hline Lake Ontario & 1636 & 6.5 & 690 & 35 & 470 & 24 & 190 & 10 & 6 & $<1$ \\
\hline
\end{tabular}

and alachlor deposited in rainfall in this part of the study area during 1991 can becompared with the masses discharged by the upper Mississippi and Ohio Rivers in streamflow. Battaglin et al. (33) estimated that $246000 \mathrm{~kg}$ of atrazine and $47900 \mathrm{~kg}$ of alachlor were discharged from this area in streamflow during April 1991-March 1992 (Table 3). Most of this transport occurred during April-September 1991. In comparison, we estimate that about $112000 \mathrm{~kg}$ of atrazine and $69000 \mathrm{~kg}$ of alachlor were deposited in rainfall on this area during January-September 1991 . These results show that theamount of atrazine deposited in rainfall on the basin was less than one-half the amount transported out of the basin in streamflow. Conversely, about one-third more alachlor was re-deposited in the Mississippi River basin through rainfall than was transported out of the basin in streamflow. An explanation for these results lies in the short soil half-lifeand higher volatility of alachlor relative to atrazine. Because alachlor has a much shorter soil half-life than atrazine, it degrades more rapidly on the soil and a much smaller fraction of thealachlor applied to cropland is available for leaching into streams. However, until degradation of alachlor occurs, it can volatilize to the atmosphere as much as 8 times faster than atrazine (29) and become available for re-deposition in rainfall. Consequently, the combination of these two effects results in a larger mass of alachlor in wet deposition than in surface runoff, the opposite of atrazine.

Deposition on theGreat Lakes. One of thesamplingsites (MI97) is located on Isle Royale in the northwest part of Lake Superior near the border of Canada and far from the U.S. cornbelt. Atrazine, presumably from the cornbelt, was detected and verified by GC/MS analysis in samples from several rain events at this site during June 1990. These data prompted the collection of water samplesfrom LakeSuperior and four small lakes on Isle Royale in late September 1990. The atrazine concentration in these samples, determined by isotope dilution methods, was $6.5 \mathrm{ng} / \mathrm{L}$ for LakeSuperior and ranged from 2.5 to $20 \mathrm{ng} / \mathrm{L}$ for the four lakes. Themain source of atrazine to LakeSuperior and the only sourcefor I sle Royale is atmospheric deposition. Using deposition rates determined from our study (see Figure 7), the annual wet deposition of atrazineand alachlor from precipitation on each of the Great Lakes was estimated. The annual wet deposition of atrazine in 1990 and 1991 ranged from more than $3600 \mathrm{~kg}$ in Lake Michigan to lessthan $500 \mathrm{~kg}$ in LakeOntario (Table4). Annual average wet deposition rates for the 2 years ranged from about $12 \mu \mathrm{g} \mathrm{m}^{-2} \mathrm{yr}^{-1}$ in Lake Superior to about $63 \mu \mathrm{g} \mathrm{m}^{-2} \mathrm{yr}^{-1}$ in
Lake Michigan. The wet deposition of alachlor wasless than atrazine, except for Lake Erie in 1990.

Schottler and Eisenreich (35) recently reported atrazine concentrations in the Great Lakes ranging from about $3 \mathrm{ng} / \mathrm{L}$ in Lake Superior to $110 \mathrm{ng} / \mathrm{L}$ in Lake Erie. They estimated the mass of atrazine stored in the water column of Lake Superior to be about $36000 \mathrm{~kg}$, which is 17-37 times larger than the estimated mass contributed to the lake by wet deposition in 1990 and 1991 and hundreds of times larger than annual atrazine inputs to the lake from surface runoff (36). Additional in put of atrazineto Lake Superior occurs via dry deposition and air-water exchange. Nevertheless, these results suggest that atrazine is slowly accumulating in Lake Superior and that degradation of atrazinein the water column of the lake is very slow. Schottler (36) has estimated the loss of atrazine from the lake by internal degradation to be about $1 \%$ per year. Accumulation of atrazine in Lake Superior will continue until the annual internal losses of atrazine equal the annual inputs.

Herbicide Metabolites in Rainfall. The triazine metabolites-deethylatrazine (DEA) and deisopropylatrazine (DIA)-were detected in $17.4 \%$ and $2.6 \%$, respectively, of the samples analyzed by GC/MS (Table 1). DEA was present in more than half (58\%) of the samples that contained atrazine and was the third most frequently detected compound. Trace concentrations of DEA were detected in 12 samples that contained no detectable atrazine. The ratio of DEA to atrazine concentrations, called the DAR, has been used to investigate surfacewater-groundwater interactions (4). LowDAR values, median $<0.1$, occur in streams during runoff shortly after application of atrazine. Higher DAR values, median about 0.4 , occur later in the year after considerable degradation of atrazine to DEA has occurred in the soil. The median DAR value calculated for the 352 rainfall samples that contained both atrazine and DEA was 0.5. All of these DAR values are from rainfall samples collected during May-July of 1990 and 1991 when the median DAR values for rivers in this area were $<0.1$ (4). Thus, considerably more DEA is present in rainfall relative to atrazine than in streams draining cornbelt states. There are several possible explanations for this observation. One hypothesis is that DEA evaporates from the soil into the atmosphere faster than atrazine, resulting in a higher DAR value in rainfall. This hypothesis cannot be fully explored however because we could find no data in the literature on the vapor pressure or Henry's law constant for DEA. The aqueous solubilities are $33 \mathrm{mg} / \mathrm{L}$ for atrazine and $3200 \mathrm{mg} / \mathrm{L}$ 
for DEA (37). Unless the vapor pressure of DEA is more than 100 times larger than for atrazine, the Henry's law constant for DEA should be similar to or smaller than that for atrazine. Thus, it seems unlikely that DEA would volatilize from soil at a significantly faster rate than atrazine.

A second hypothesis for the high DAR value in rainfall is that atrazine may be transformed to deethylatrazine in the atmosphere by photochemical processes. Studies of photocatalytic degradation and ozone oxidation of atrazine have shown deethylatrazineto bea degradation product of atrazine. For example, Pelizzetti et al. (38) proposed that atrazine degrades through an atrazine amide to DEA and then forms a didealklyated product. Kearney et al. (39) showed that ozone treatment of herbicide wasteyielded both the atrazine amide and deethylatrazine. Thus, it is possible that the high DAR values of 0.5 in rainfall reflect the photocatalyzed degradation of atrazine in the atmosphere. If we presume that the DAR values for evaporating water are similar to surface runoff (i.e., 0.1 ) and that the DAR for rainfall is 0.5 , then there is about a $25-30 \%$ conversion of atrazine to deethylatrazine during its residencetimein theatmosphere. Moreresearch isneeded to better understand the processes and pathways for atmospheric degradation of atrazine and other pesticides.

\section{Acknowledgments}

This research was conducted as part of the U.S. Geological Survey's Toxic Substances Hydrology Program. The rainfall samples used to conduct this study were obtained through the cooperation and support of the National Atmospheric Deposition Program/National Trends Network, Ft. Collins, $\mathrm{CO}$, and the Illinois State Water Survey, Urbana, IL. The encouragement and support provided by Gail Mallard of the USGS, Carol Simmons of NAPD/NTN, and Mark Peden and Kathy Douglas of the Illinois State Water Survey are greatly appreciated.

\section{Literature Cited}

(1) Gianessi, L. P.; Puffer, C. M. Herbicide Use in the United States; Resources for the Future, Quality of the Environment Division: Washington, DC, 1991

(2) Aspelin, A. L. Pesticide Industry Sales and U sage, 1992 and 1993 Market Estimates; U.S. Environmental Protection Agency: Washington, DC, 1994; EPA/ 733-K-94-001.

(3) Wauchope, R. D. J. Environ. Qual. 1978, 7, 459-472.

(4) Thurman, E. M.; Goolsby, D. A.; Meyer, M. T.; Kolpin, D. W. Environ. Sci. Technol. 1992, 26, 2440-2447.

(5) Baker, D. B.; Richards, R. P. In Pesticides in the Terrestrial and Aquatic Environments, Proceedings of a National Research Conference; Blacksburg, VA, 1989; pp 103-120.

(6) Goolsby, D. A.; Battaglin, W. A.; Thurman, E. M. U.S. Geol. Surv. Circ (U.S.). 1993, No. 1120-C.

(7) Pereira, W. E.; Hostettler, F. D. Environ. Sci. Technol. 1993, 27, $1542-1552$.

(8) Hallberg, G. R. Agric. Ecosyst. Environ. 1989, 26, 299-367.

(9) Holden, L. R.; Graham, J. A.; Whitmore, R. W.; Alexander, W. J.; Pratt, R. W.; Liddle, S. K.; Piper, L. L. Environ. Sci. Technol. 1992, 26, 935-943.

(10) Burkart, M. R.; Kolpin, D. W. J. Environ. Qual. 1993, 22, 646656.

(11) Eisenreich, S. J.; Looney, B. B.; Thornton, J. D. Environ. Sci. Technol. 1981, 15, 30-38.

(12) Glotfelty, D. E.; Seiber, J. N.; Lilijahl, L. A. Nature 1987, 325, 602-605.

(13) Capel, P. D. Water Resour. Invest. (U.S. Geol. Surv.) 1991, No. 91-4034, 334-337.
(14) Nations, B. K.; Hallberg, G. R. J. Environ. Qual. 1992, 21, 486492.

(15) Richards, P. R.; Kramer, J. W.; Baker, D. B.; Kreiger, K. A. Nature 1987, 327, 129-131.

(16) Williams, A. L.; Sweet, C. W.; Peters, C. In Proceedings of the 85th Annual Meetingand Exhibition of theAir and WasteManagement Association; 1992; pp 2-12.

(17) Tierney, D. P. Biological Assessment of Atrazineand Metolachlor in Rainfall: Technical Paper 1-1993; Ciba-Geigy Corporation: Greensboro, NC, 1993; $16 \mathrm{pp}$

(18) Glotfelty, D. E.; Williams, G. H.; Freeman, H. P.; Leech, M. M. In Long Range Transport of Pesticides; Kurtz, D. L., Ed.; Lewis Publishers: Chelsea, MI, 1990; pp 199-221.

(19) Wu, T. L. Water, Air, Soil Pollut. 1981, 15, 173-184.

(20) Majewski, M. S.; Capel, P. D. Pesticides in the Atmosphere-Distribution Trends, and Governing Factors; Ann Arbor Press: Chelsea, MI, 1995; pp 88-110.

(21) Waite, D. T.; Grover, R.; Wescott, N. D.; Irvine, D. G.; Kerr, L. A.; Sommerstad, H. Environ. Toxicol. Chem. 1995, 14, 1171-1175.

(22) Buser, H. R. Environ. Sci. Technol. 1990, 24, 1049-1058.

(23) Trevisan, M.; Montepiani, C.; Ragozza, L.; Bartoletti, C.; I oannilli, E.; Del Re, A. A. M. Environ. Pollut. 1993, 80, 31-39.

(24) National Atmospheric Deposition Program. NADP/NTN Annual Data Summary, Precipitation Chemistry in the United States, 1991; National Resource Ecology Laboratory, Colorado State University: Fort Collins, CO, 1992; 475 pp.

(25) Taylor, J. K. QualityAssuranceof Chemical Measurements; Lewis Publishers: Chelsea, MI, 1987; pp 22.

(26) Meyer, M. T.; Mills M. S.; Thurman, E. M. J. Chromatogr. 1993, 629, 55-59.

(27) Thurman, E. M.; Meyer, M. T.; Pomes, M. L.; Perry, C. A.; Schwab, A. P. Anal. Chem. 1990, 62, 2043-2048.

(28) Goolsby, D. A.; Scribner, E. A.; Thurman, E. M.; Pomes, M. L.; Meyer, M. T. Open-FileRep.-U.S. Geol. Surv. 1995, No. 95-469.

(29) Glotfelty, D. E.; Leech, M. M.; Jersey, J.; Taylor, A. W. J. Agric. Food Chem. 1989, 37, 546-551.

(30) U.S. Department of Agriculture. The ARS pesticide properties database; 1995; available on the Internet at http:// www.arsusda.gov/ history.html.

(31) Becker, R. L.; Hergfel, D.; Ostlie, K. R.; Stamm-Katovick, E. J. Pesticides-Surface Runoff, Leaching, and Exposure Concerns; University of Minnesota Extension Service Publication AG-BU3911; 1989; 32 pp.

(32) Foreman, W. F.; Gates, P. M.; DeGiacomo, W. G.; Anderson, L. G. Water Resour. Invest. (U.S. Geol. Surv.) 1991, No. 91-4034, 219-222.

(33) Battaglin, W. A.; Goolsby, D. A. Water Resour. Invest. (U.S. Geol. Surv.) 1994, No. 94-4176.

(34) Eisenreich, S. J.; Baker, J. E.; Franz, T.; Swanson, M.; Rapport R. A.; Strachan, W. M. J.; Hites, R. A. Fate of Pesticides and Chemicalsin theEnvironment; John Wiley and Sons: New York, 1992; pp 51-78.

(35) Schottler, S. P.; Eisenreich, S. J. Environ. Sci. Technol. 1994, 28, 2228-2232.

(36) Schottler, S. P. Ph.D. Thesis, University of Minnesota, 1996.

(37) Mills, M. S.; Thurman, E. M. Environ. Sci. Technol. 1994, 28, 73-79.

(38) Pelizzetti, E.; Maurino, V; Minero, C.; Carlin, V.; Pramauro, E.; Zerbinati, O.; Tosato, M. L. Environ. Sci. Technol. 1990, 24, 15591565.

(39) Kearney, P. C.; Muldoon, M. T.; Somich, C. J.; Ruth, J. M.; Voaden, D. J. J. Agric. Food Chem. 1988, 36, 1301-1306.

Received for review October 2, 1996. Revised manuscript received January 13, 1997. Accepted January 17, 1997. ${ }^{\otimes}$

\section{ES9608470}

${ }^{\otimes}$ Abstract published in Advance ACS Abstracts, March 15, 1997. 